\title{
Removal of Radium from Synthetic Shale Gas Brines by lon Exchange Resin
}

\author{
Yuqiang Bi, ${ }^{\dagger}$ Hui Zhang, Brian R. Ellis, ${ }^{\dagger}$ and Kim F. Hayes* \\ Department of Civil and Environmental Engineering, University of Michigan, Ann Arbor, Michigan.
}

Received: January 3, $2016 \quad$ Accepted in revised form: June 21, 2016

\begin{abstract}
Rapid development of hydraulic fracturing for natural gas production from shale reservoirs presents a significant challenge related to the management of the high-salinity wastewaters that return to the surface. In addition to high total dissolved solids (TDS), shale gas-produced brines typically contain elevated concentrations of radium ( $\mathrm{Ra}$ ), which must be treated properly to prevent contamination of surface waters and allow for safe disposal or reuse of produced water. Treatment strategies that isolate radium in the lowest volume waste streams would be desirable to reduce disposal cost and generate useful treatment by-products. The present study evaluates the potential of a commercial strong acid cation exchange resin for removing $\mathrm{Ra}^{2+}$ from high-TDS brines using fixed-bed column reactors. Column reactors were operated with varying brine chemistries and salinities in an effort to find optimal conditions for $\mathrm{Ra}^{2+}$ removal through ion exchange. To overcome competing divalent cations present in the brine for exchange sites, the chelating agent, EDTA, was used to form stable complexes predominantly with the higher concentration $\mathrm{Ca}^{2+}, \mathrm{Mg}^{2+}$, and $\mathrm{Sr}^{2+}$ divalent cations, while isolating the much lower concentration $\mathrm{Ra}^{2+}$ species. Results showed that $\mathrm{Ra}^{2+}$ removal by the resin strongly depended on the TDS concentration and could be improved with careful selection of EDTA concentration. This strategy of metal chelation coupled with ion exchange resins may be effective in enhancing $\mathrm{Ra}^{2+}$ removal and reducing the generation and disposal cost if volume reduction of low-level radioactive solid waste can be achieved.
\end{abstract}

Keywords: chelating agent; high salinity; ion exchange; radium; shale-gas wastewater

\section{Introduction}

A PPLICATION OF HORIZONTAL DRILLING and high-volume hydraulic fracturing has enabled access to previously unrecoverable natural gas in unconventional reservoirs around the globe (Kerr, 2010; Moniz et al., 2011). In the United States, natural gas extracted from shale formations is predicted to comprise $\sim 50 \%$ of all domestic natural gas production by 2040 (U.S. Energy Information Administration, 2015). The rapid expansion of shale gas development, however, has raised increasing concerns over the consequent impact on freshwater supply and quality. Due to the limited availability of freshwater sources in some regions, and a lack of easy disposal options in others, recycling and reuse of flowback water are becoming an attractive shale gas wastewater management strategy (Gregory et al., 2011; Rahm et al., 2013).

*Corresponding author: Department of Civil and Environmental Engineering, University of Michigan, 2340 G.G. Brown Lab, 2350 Hayward Street, Ann Arbor, MI 48109-2125. Phone: (734) 7648495; Fax: (734) 764-4292; E-mail: ford@umich.edu ${ }^{\dagger}$ Member of AEESP.
While recycling and reuse of flowback water rely on adequate treatment, the presence of naturally occurring radionuclide materials (NORMs) at elevated levels in these waters poses a unique challenge to conventional treatment strategies. For example, Marcellus Shale-produced water contains total radium $(\mathrm{Ra})$ activity up to 18,000 picocuries per liter (pCi/L), with a median value of $2,470 \mathrm{pCi} / \mathrm{L}$ (Rowan, 2011). Current EPA regulations, in comparison, mandate that $\mathrm{Ra}$ activities in drinking water and industrial effluents must be below 5 and $60 \mathrm{pCi} / \mathrm{L}$, respectively (U.S. Nuclear Regulatory Commission, 2013). Conventional treatment technologies, such as osmosis, distillation, and electrodialysis, are either cost prohibitive or nonselective for Ra removal from flowback wastewater (Fakhru'l-Razi et al., 2009). Soluble over a wide range of $\mathrm{pH}$ and redox conditions, radioisotopes, ${ }^{226} \mathrm{Ra}$ and ${ }^{228} \mathrm{Ra}$, can be easily transported from geologic reservoirs to surface facilities, together with an abundance of alkaline metals and organic compounds (Fisher, 1995). Radium activity in produced waters has been found to positively correlate with total dissolved solid (TDS) concentrations, particularly from Marcellus Shale wells (Fisher, 1998; Rowan, 2011). Previous studies have implicated the accumulation of $\mathrm{Ra}$ in stream sediments of western Pennsylvania due to inadequate 
removal of Ra from high-salinity NORM-rich Marcellus waste fluids (Warner et al., 2013). High Ra levels were also observed in reserve pit sludge from hydraulic fracturing and drilling activities (Rich, 2013). The exposure of Ra through inhalation and ingestion can introduce an internal dose of radioactivity and potentially cause cancer (Boice and Lubin, 1997). The decay products of $\mathrm{Ra}$, that is, gaseous and highly toxic radon $(\mathrm{Rn})$, can lead to an additional health hazard (Zhang et al., 2015). Therefore, effective management of the large volumes of wastewaters containing dissolved $\mathrm{Ra}$ isotopes is required to minimize the environmental and health risks.

The most cost-effective existing approach to remove $\mathrm{Ra}$ from high-TDS brines is sulfate precipitation (Zhang et al., 2014). Radium coprecipitates with barite $\left[\mathrm{BaSO}_{4}(\mathrm{~s})\right]$ during secondary treatment to remove $\mathrm{Ba}^{2+}$ from brine, generating $(\mathrm{Ba}, \mathrm{Ra}) \mathrm{SO}_{4}$ solid solution with a $\mathrm{Ba}: \mathrm{Ra}$ ratio on the order of 1,000:6 (Grandia et al., 2008). However, this strategy may result in large volumes of low-level radioactive $(\mathrm{Ba}, \mathrm{R}$ a) $\mathrm{SO}_{4}(\mathrm{~s})$ sludge that must be properly disposed of in landfills permitted to handle this type of waste material. Such sludge by-products, classified as technology enhanced-NORM (TENORM), may contain radioactivity far exceeding the threshold values of management regulations in the United States and require additional dilution with NORM-free solids for safer handling (Zhang et al., 2014). To reduce disposal cost and enhance the potential for reuse or sale of barite or other salt residuals, novel approaches to remove or separate Ra from the salts and nontoxic substances present in shale gas wastewater are highly desired.

This study is motivated by the need to effectively separate $\mathrm{Ra}$ from shale gas production wastewater to reduce the volume of Ra-contaminated phases during treatment steps. Solid-phase partitioning provides an opportunity to concentrate $\mathrm{Ra}$ in a lower volume solid waste form and, in some cases, could allow subsequent separation steps (e.g., coprecipitation) to produce solid phases that are almost Ra-free, with potential commercial value (e.g., barite and $\mathrm{CaCl}_{2}$ salts). Ion exchange materials are potentially well suited for the removal of $\mathrm{Ra}$ and other ionic species due to relatively high removal efficiency, low regeneration costs, and effective response to alternations of pollutant concentration levels (International Atomic Energy Agency, 2002; Chalupnik et al., 2013). Cation exchange resins have been successfully used for the removal of naturally occurring $\mathrm{Ra}$ in groundwater (Snoeyink et al., 1987; Deng, 2005; El-Shrakawy et al., 2013). The effective application of resin in the treatment of high-TDS brines associated with shale gas production, however, has not been demonstrated.

The present work aims to test the feasibility of using ion exchange resin to effectively remove Ra from synthetic highTDS brines. The cation exchange reaction was performed in a fixed-bed column reactor packed with Purolite ${ }^{\circledR} \mathrm{C} 100 \mathrm{E}$ resin. The concentrations of individual salt and TDS in the synthetic brines were varied to examine their influence on $\mathrm{Ra}$ removal capacity and efficiency of the resin. The chelating agent EDTA was added to enhance Ra removal by reducing the competition from divalent cations for exchange sites. The combined effects of varying salinity and EDTA concentration were also investigated to determine the optimal levels of EDTA for enhancing $\mathrm{Ra}$ ion exchange. The results provide a first assessment of the capacity and controlling factors of ion exchange processes for Ra removal from high-TDS brines, which have practical implications for developing ion exchange processes for treating NORMs in shale gas wastewater.

\section{Materials and Methods}

\section{Reagents and samples}

Unless stated otherwise, all chemicals used for solution preparation were of analytical reagent grade. MilliQ water with a resistivity of $18.3 \mathrm{M} \Omega \cdot \mathrm{cm}$ was used throughout. Raw, synthetic brine solutions containing sodium, magnesium, calcium, barium, and strontium were prepared in the laboratory by dissolving $\mathrm{NaCl}, \mathrm{MgCl}_{2} \bullet 6 \mathrm{H}_{2} \mathrm{O}, \mathrm{CaCl}_{2} \bullet 2 \mathrm{H}_{2} \mathrm{O}$, $\mathrm{BaCl}_{2} \bullet 2 \mathrm{H}_{2} \mathrm{O}$, and $\mathrm{SrCl}_{2} \bullet 6 \mathrm{H}_{2} \mathrm{O}$ salts in a $1-\mathrm{L}$ volumetric flask. The resulting ion concentrations covered a range of ion mixtures and levels of TDS (4,500-69,800 mg/L), which are close to median values of typical brine composition of Marcellus Shale gas fluids. In this study, Ra was used to represent total $\mathrm{Ra}$ isotopes under the assumption that ${ }^{226} \mathrm{Ra}$ and ${ }^{228} \mathrm{Ra}$ have similar ion exchange behavior. A stock ${ }^{226} \mathrm{Ra}\left(\mathrm{NO}_{3}\right)_{2}$ standard solution in $1 \mathrm{M} \mathrm{HNO}_{3}$ was purchased from Eckert \& Ziegler (Catalog No. 7226) at a radioactivity of $10.6 \mu \mathrm{Ci} / \mathrm{L}$. One milliliter of the $\mathrm{Ra}$ stock solution was added to the 1-L flask to achieve a final activity of $10.6 \mathrm{nCi}-$ $\mathrm{Ra} / \mathrm{L}$. The $\mathrm{pH}$ of the initial solution was then adjusted to $\mathrm{pH}$ 2 or 6 using a $1 \mathrm{M}$ hydrochloric acid or sodium hydroxide solution, respectively. A summary of chemical properties of the synthetic brine solutions used in this study is provided in Table 1 and Supplementary Table S1.

To test the effect of metal-complexing ligand on Ra removal by ion exchange, high-TDS water was amended with varied concentrations of ethylenediaminetetraacetic acid disodium salt (disodium-EDTA) before passing through a resin column. Disodium EDTA salt was dissolved in the Racontaining solution described above by adjusting the solution $\mathrm{pH}$ to a value of 6 . The $\mathrm{pH}$ value was selected to facilitate dissolution of EDTA and complexation of deprotonated EDTA with metal cations. The solution was then continuously stirred overnight to reach equilibrium for metal complexation. The final EDTA concentration in the high-TDS water was adjusted to be approximately the same value as the total divalent cation concentration. The purpose of doing so was to complex nearly all of the higher concentration divalent cations (i.e., $\mathrm{Mg}^{2+}, \mathrm{Ca}^{2+}, \mathrm{Sr}^{2+}$, and $\mathrm{Ba}^{2+}$ ) with EDTA to limit their potential for competition with $\mathrm{Ra}^{2+}$ for ion exchange sites. Speciation modeling simulations (Supplementary Fig. S1) showed that this strategy was feasible for isolating free $\mathrm{Ra}^{2+}$ from other divalent cations present. Most divalent ions except $\mathrm{Ra}^{2+}$ were complexed by EDTA, so their interactions with cation exchange resin would be minimized.

Commercial SAC resin. Purolite $\mathrm{C} 100 \mathrm{E}$ is an inexpensive Na-form strong acid cation (SAC) exchange resin with a macroreticular cross-linked polystyrene-divinylbenzene (DVB) matrix structure and anionic sulfonate groups. This resin has been commonly used for industrial water softening and demineralization due to its high affinity for alkaline earth metals and heavy metals (Abo-Farha et al., 2009; Radosavlevici and Robescu, 2013). A package of 1 pound of resin was supplied by Purolite (Bala Cynwyd, PA). The total capacity of this resin, defined as the total number of charge equivalents available for exchange per 
Table 1. Chemical Properties of Synthetic High-TdS Brines Used for Ra Removal by Purolite ${ }^{\circledR}$ C100E Cation Exchange Resin

\begin{tabular}{|c|c|c|c|c|c|c|c|c|c|c|c|}
\hline \multirow[b]{2}{*}{$\begin{array}{l}\text { Experiment } \\
\text { No. }\end{array}$} & \multicolumn{6}{|c|}{$\begin{array}{l}\text { Synthetic brine composition } \\
\text { (mM; except for TDS) }\end{array}$} & \multirow[b]{2}{*}{$\begin{array}{c}R a^{2+} \\
(\mathrm{nCi} / \mathrm{L})\end{array}$} & \multirow[b]{2}{*}{$\begin{array}{c}\text { EDTA } \\
(M)\end{array}$} & \multirow[b]{2}{*}{$p H$} & \multirow[b]{2}{*}{$\begin{array}{c}\text { Capacity } \\
\text { for } \operatorname{Ra}(n C i / g)\end{array}$} & \multirow[b]{2}{*}{$\begin{array}{l}\text { Ra removal } \\
\text { efficiency }(\%)\end{array}$} \\
\hline & $\mathrm{Na}^{+}$ & $M g^{2+}$ & $\mathrm{Ca}^{2+}$ & $S r^{2+}$ & $B a^{2+}$ & $\begin{array}{l}T D S \\
(m g / L)\end{array}$ & & & & & \\
\hline 1 & 650 & 21.0 & 98.0 & 10.3 & 0.9 & 52,836 & 10.6 & 0 & 2.0 & $0.24 \pm 0.01$ & 50 \\
\hline 2 & 0 & 21.1 & 99.9 & 10.3 & 0.9 & 14,925 & 10.6 & 0 & 2.0 & $0.36 \pm 0.01$ & 61 \\
\hline 3 & 650 & 9.7 & 46.2 & 4.5 & 0.4 & 40,839 & 10.6 & 0 & 2.0 & $0.38 \pm 0.02$ & 68 \\
\hline 4 & 70 & 2.2 & 11.0 & 1.1 & 0.1 & 4,497 & 10.6 & 0 & 2.0 & $>0.46 \pm 0.02$ & 100 \\
\hline 5 & 660 & 21.3 & 102.1 & 10.4 & 0.9 & 44,197 & 10.6 & 0.135 & 6.0 & $0.42 \pm 0.02$ & 43 \\
\hline 6 & 880 & 20.3 & 98.7 & 10.2 & 0.9 & 54,058 & 10.6 & 0.170 & 6.0 & $0.04 \pm 0.01$ & 23 \\
\hline 7 & 480 & 21.2 & 99.6 & 10.4 & 0.9 & 33,385 & 10.6 & 0.135 & 6.0 & $0.65 \pm 0.03$ & 66 \\
\hline 8 & 1,120 & 19.1 & 93.3 & 9.7 & 0.8 & 69,757 & 10.6 & 0.135 & 6.0 & $0.12 \pm 0.01$ & 40 \\
\hline 9 & 930 & 17.6 & 91.9 & 9.3 & 0.8 & 60,074 & 10.6 & 0.110 & 6.0 & $0.22 \pm 0.01$ & 45 \\
\hline
\end{tabular}

Supplementary Table S1 shows different units for concentration (ppm) and radioactivity $(\mathrm{Bq})$ of radium.

TDS, total dissolved solids.

unit weight, is $\sim 2.2 \mathrm{meq} / \mathrm{g}$. Other characteristics of the resin are listed in Table 2.

\section{Method approach}

Fixed-bed column for Ra removal by Purolite resin. Column experiments were carried out in fixed-bed glass columns (10 mm i.d., $300 \mathrm{~mm}$ depth) (Kimble-Chase Kontes ${ }^{\mathrm{TM}}$ ) consisting of a glass barrel and two PTFE end fittings with $20 \mu \mathrm{m}$ porosity polyethylene bed supports. A schematic of the column reactor system used in this study is shown in Figure 1. The column was uniformly packed with $10.2 \mathrm{~g}$ Purolite C100E resin, which corresponds to a bed volume (BV) of $\sim 12 \mathrm{~cm}^{3}$. Before the start of experiment, the column was backwashed by MilliQ water so that the resin was suspended for $30 \mathrm{~min}$ to remove air bubbles trapped between particles. For the experiments amended with EDTA, the resin was preconditioned by $100 \mathrm{~mL}$ of $100 \mathrm{~g} / \mathrm{L}(1.7 \mathrm{M}) \mathrm{NaCl}$ solution to remove residual $\mathrm{H}^{+}$in the resin. The preconditioning process included two stages: a slow rinse with a flow rate of $1.5 \mathrm{~mL} / \mathrm{min}$ for $45 \mathrm{~min}$, followed by a final rinse at $2 \mathrm{~mL} / \mathrm{min}$ for $18 \mathrm{~min}$. The resin was then rinsed by $100 \mathrm{~mL}$ MilliQ water in counterflow mode and allowed to settle by gravity for a compact bed. Preconditioning allowed a stable effluent $\mathrm{pH}$ to be maintained at high salinity during $\mathrm{Ra}^{2+}$ removal.

During column operation, $1 \mathrm{~L}$ of high-TDS water containing $\sim 10.6 \mathrm{nCi} / \mathrm{L} \mathrm{Ra}$ was pumped downward through the column at a flow rate of $\sim 1.2 \mathrm{~mL} / \mathrm{min}$ using a Masterflex 7553 peristaltic pump (Cole-Parmer Instrument Co., Vernon Hills, IL). Varied salt concentration was used to investigate the impact of TDS on ion exchange. EDTA-amended high-TDS water was used for reducing salt interference and improving $\mathrm{Ra}^{2+}$ removal. The empty bed contact time was designed to be $\sim 10 \mathrm{~min}$. Periodically, the $\mathrm{pH}$ and conductivity of the effluent were monitored with probes installed at the end of the supply line. Samples of $\sim 4 \mathrm{~mL}$ were collected from the effluent end of the column every $30 \mathrm{~min}$. The samples were then acidified with $2 \%$ nitric acid ( $\mathrm{pH}$ $<2$ ) and transferred to high-density polyethylene plastic tubes. All samples were stored in a refrigerator at $4^{\circ} \mathrm{C}$ before measurement, and then analyzed within 1 week of sample collection date. In all experiments, the resin columns were eluted up to exhaustion to obtain the complete $\mathrm{S}$-shape $\mathrm{Ra}^{2+}$ breakthrough curve, which was plotted as BVs of processed wastewater vs. effluent $\mathrm{Ra}^{2+}$ concentration. Most experiments were run in duplicates to test the reproducibility of $\mathrm{Ra}^{2+}$ removal under a given set of experimental conditions. All experiments were performed at room temperature $\left(23^{\circ} \mathrm{C} \pm 1^{\circ} \mathrm{C}\right)$.

Ra measurement. An Agilent 7900 inductively coupled plasma mass spectrometer (ICP-MS) was used to determine the concentrations of ${ }^{226} \mathrm{Ra}$ and other major cations (i.e., $\mathrm{Na}$, $\mathrm{Ca}, \mathrm{Mg}, \mathrm{Sr}$, and $\mathrm{Ba}$ ) in reference standards and samples. The measurement of $\mathrm{Ra}$ was conducted in HEHe mode using a nonreactive helium gas and kinetic energy discrimination process. Detection limit was determined to be $0.1 \mathrm{ng} / \mathrm{L}$ (equal to $0.1 \mathrm{nCi}-\mathrm{Ra} / \mathrm{L}$ ). The uncertainty of Ra measurement by ICPMS was estimated to be $10 \%$ above $0.5 \mathrm{nCi} / \mathrm{L}$ and $>20 \%$ below $0.5 \mathrm{nCi} / \mathrm{L}$. The effluent samples were diluted with $2 \%$ nitric acid before analysis to limit interference during metal analysis. The reproducibility of this analytical procedure is within 5\% for alkaline metals. Details of instrument components, operating conditions, and data acquisition parameters are summarized in the Supporting Information (Supplementary Table S2).

Mathematical description. The concentration of $\mathrm{Ra}(\mathrm{nCi} / \mathrm{g})$ and other metal ions ( $\mathrm{mmol} / \mathrm{g}$ ) bound on the resin at equilibrium $\mathrm{Q}_{\mathrm{E}}$ corresponds to the maximum capacity of the resin at

Table 2. Characteristics of Purolite C100E Cation Exchange Resin

\begin{tabular}{lcccccc}
\hline Resin & Type & Structure & $\begin{array}{c}\text { Particle } \\
\text { size }(\mu \mathrm{m})\end{array}$ & $\begin{array}{c}\text { Capacity } \\
(\mathrm{meq} / \mathrm{mL})\end{array}$ & $\begin{array}{c}\text { Capacity } \\
(\text { meq/g) }\end{array}$ & $\begin{array}{c}\text { Moisture } \\
\text { retention }(\%)\end{array}$ \\
\hline Purolite C100E & Gel (Na+ form) & polystyrene & $300-1200$ & $\geq 1.9$ & $\geq 2.2$ & $46-50$ \\
\hline
\end{tabular}




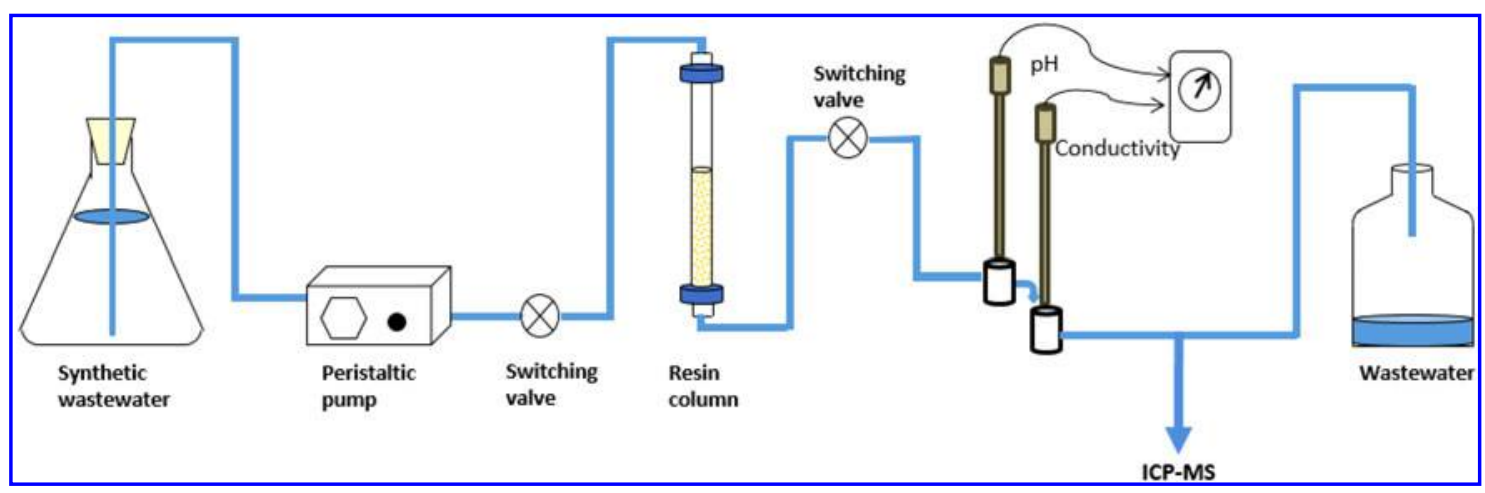

FIG. 1. Schematic of fixed-bed column reactor system for $\mathrm{Ra}^{2+}$ removal by Purolite ${ }^{\circledR} \mathrm{C} 100 \mathrm{E}$ cation exchange resin.

the exhaustion point $\mathrm{q}_{\mathrm{E}}$, and it is defined as the total amount of metal ions bound per gram of resin at the exhaustion time:

$$
\mathrm{Q}_{\mathrm{E}}=\mathrm{q}_{\mathrm{E}}=\frac{\mathrm{n}_{\mathrm{E}}}{\mathrm{m}}
$$

where $\mathrm{n}_{\mathrm{E}}$ ( $\mathrm{nCi}$ or mmol) is the quantity of metals bound during the process in the column and $\mathrm{m}(\mathrm{g})$ the mass of resin. The total quantity of metals bound in a fixed bed of resin for a given feed concentration and flow rate through the column is determined by integrating the area above the breakthrough curve and can be calculated according to the following equation:

$$
\mathrm{n}_{\mathrm{E}}=\mathrm{Q} \int_{0}^{\mathrm{t}_{\mathrm{E}}}\left(\mathrm{c}_{0}-\mathrm{c}\right) \mathrm{dt}
$$

where $\mathrm{n}_{\mathrm{E}}(\mathrm{nCi}$ or mmol) is the total amount of metal ions bound in a fixed bed of resin; $\mathrm{c}_{0}(\mathrm{nCi} / \mathrm{L}$ or $\mathrm{mmol} / \mathrm{L})$ is influent concentration; $\mathrm{c}(\mathrm{nCi} / \mathrm{L}$ or $\mathrm{mmol} / \mathrm{L})$ is effluent concentration of metal ions; $\mathrm{Q}(\mathrm{L} / \mathrm{h})$ is flow rate; $\mathrm{t}(\mathrm{h})$ is time; and $\mathrm{t}_{\mathrm{E}}(\mathrm{h})$ is time necessary to reach the point of exhaustion of the resin bed.

The total amount of metal ions $\mathrm{n}_{\mathrm{T}}$ ( $\mathrm{nCi}$ or mmol) that enter the resin column is calculated by the following equation:

$$
\mathrm{n}_{\mathrm{T}}=\mathrm{c}_{0} \cdot \mathrm{Q} \cdot \mathrm{t}_{\mathrm{E}}
$$

The $\mathrm{Ra}^{2+}$ removal efficiency by resin is defined as the ratio of the total quantity of $\mathrm{Ra}^{2+}$ removed until exhaustion $\left(\mathrm{n}_{\mathrm{E}}\right)$ to the total amount of Ra sent to the column $\left(\mathrm{n}_{\mathrm{T}}\right)$ and is given by the following equation:

$$
\text { Removal efficiency }(\%)=\left(\mathrm{n}_{\mathrm{E}} / \mathrm{n}_{\mathrm{T}}\right) \cdot 100
$$

\section{Results and Discussion}

\section{Preferential removal of $\mathrm{Ra}$ by ion exchange resin}

Synthetic high-TDS brine containing Ra (Table 1) was treated by directly passing it through fixed-bed column reactors packed with Purolite C100E resin. Figure 2 shows an example (Experiment No. 1) of breakthrough curves of $\mathrm{Na}^{+}$, $\mathrm{Mg}^{2+}, \mathrm{Ca}^{2+}, \mathrm{Ba}^{2+}, \mathrm{Sr}^{2+}$, and $\mathrm{Ra}^{2+}$ collected in the effluent as a function of time. With TDS of $\sim 52,800 \mathrm{mg} / \mathrm{L}$, the SAC resin showed preferential removal of divalent cations, which followed the order of $\mathrm{Ra}^{2+}>\mathrm{Ba}^{2+}>\mathrm{Sr}^{2+}>\mathrm{Ca}^{2+}>\mathrm{Mg}^{2+}$. The $\mathrm{Ra}^{2+}$ remained negligible in the effluent for the first nine $\mathrm{BVs}$, after which the concentration continuously increased over the next $30 \mathrm{BVs}$ until reaching the initial influent concentration $(10.6 \mathrm{nCi} / \mathrm{L})$. The slope of the breakthrough curve indicates incomplete removal of $\mathrm{Ra}^{2+}$ by the resin before its exhaustion. The removal efficiency [Eq. (4)] is estimated to be $50 \%$, indicating the presence of a concentration gradient of $\mathrm{Ra}^{2+}$ within the column. Duplicate experiments demonstrate consistent resin performance for Ra removal from this high-TDS water. The total capacity of resin for $\mathrm{Ra}^{2+}$ based on the breakthrough curve [Eq. (2)] is estimated to be $2.47 \mathrm{nCi}$, with a mass-normalized working capacity of $0.24 \pm 0.06 \mathrm{nCi} / \mathrm{g}$.

At a feed concentration of $0.94 \mathrm{mM}$, the breakthrough of $\mathrm{Ba}^{2+}$ occurred slightly before $\mathrm{Ra}^{2+}$, taking $\sim 30 \mathrm{BVs}$ until the resin reached saturation. Compared with the $\mathrm{Ra}^{2+}, \mathrm{Ba}^{2+}$ concentration in the effluent increased at a faster rate, reflected by a steeper slope of the breakthrough curve. Between 10 and $30 \mathrm{BVs}$, clear separation between $\mathrm{Ba}^{2+}$ and $\mathrm{Ra}^{2+}$ was achieved by the SAC resin. By the time the effluent concentration of $\mathrm{Ra}^{2+}$ reached the concentration of $\sim 1.0 \mathrm{nCi} / \mathrm{L}$, the $\mathrm{Ba}^{2+}$ effluent concentration was already $38 \%$ of its influent value $(0.36 \mathrm{mM})$. The higher selectivity for $\mathrm{Ra}^{2+}$ reflects greater affinity of the resin for larger

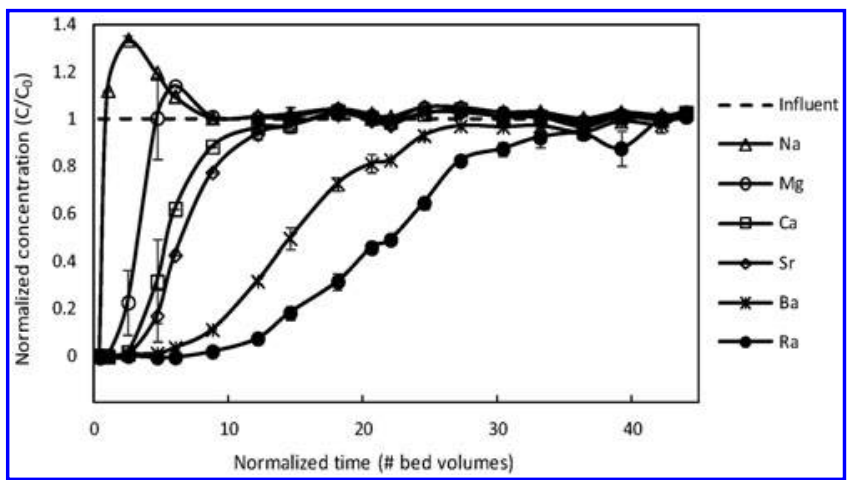

FIG. 2. Breakthrough curves of $\mathrm{Na}^{+}, \mathrm{Mg}^{2+}, \mathrm{Ca}^{2+}, \mathrm{Ba}^{2+}$ $\mathrm{Sr}^{2+}$, and $\mathrm{Ra}^{2+}$ during the treatment of synthetic high-TDS brines by Purolite C100E cation exchange resin. Concentrations of cations are normalized to the influent values $\left(\mathrm{C} / \mathrm{C}_{0}\right)$. Data points are the average concentrations of duplicate experiments; error bars for each point represent the range of concentration from duplicate experiments. TDS, total dissolved solids. 
Table 3. Calculated Removal Capacity of C100E Resin for the Four Competitive Divalent Cations, Overall Ion Exchange Capacity, and Utilized Total Capacity for Cation Exchange

\begin{tabular}{|c|c|c|c|c|c|c|}
\hline \multirow[b]{2}{*}{ Experiment No. } & \multicolumn{4}{|c|}{ Removal of four divalent cations by C100E resin $(\mathrm{mmol} / \mathrm{g})$} & \multirow{2}{*}{$\begin{array}{c}\text { Total resin } \\
\text { capacity }(\text { meq/g) }\end{array}$} & \multirow{2}{*}{$\begin{array}{c}\text { Utilized } \\
\text { cation exchange } \\
\text { capacity }(\%)^{\mathrm{a}}\end{array}$} \\
\hline & $M g^{2+}$ & $\mathrm{Ca}^{2+}$ & $S r^{2+}$ & $B a^{2+}$ & & \\
\hline 1 & 0.05 & 0.59 & 0.08 & 0.02 & $1.46 \pm 0.07$ & 66.3 \\
\hline 2 & 0.05 & 0.94 & 0.12 & 0.02 & $2.28 \pm 0.11$ & 103.4 \\
\hline 3 & 0.01 & 0.31 & 0.04 & 0.01 & $0.73 \pm 0.04$ & 33.3 \\
\hline 4 & 0.12 & 0.71 & 0.07 & 0.01 & $1.83 \pm 0.09$ & 83.2 \\
\hline 5 & 0.00 & 0.00 & 0.01 & 0.02 & $0.05 \pm 0.04$ & 2.2 \\
\hline 6 & 0.00 & 0.00 & 0.00 & 0.00 & $0.00 \pm 0.01$ & 0.2 \\
\hline 7 & 0.03 & 0.30 & 0.02 & 0.03 & $0.76 \pm 0.12$ & 34.4 \\
\hline 8 & 0.02 & 0.09 & 0.01 & 0.01 & $0.25 \pm 0.03$ & 11.4 \\
\hline 9 & 0.00 & 0.00 & 0.03 & 0.01 & $0.08 \pm 0.01$ & 3.5 \\
\hline
\end{tabular}

The removal of different divalent cations by the resin was calculated based on their individual breakthrough curves.

${ }^{a}$ Utilized capacity is the ratio of calculated total resin capacity to the theoretical capacity $(2.2 \mathrm{meq} / \mathrm{g})$.

cations, which have lower hydration energy and greater ability to shed waters of hydration upon ion exchange (International Atomic Energy Agency, 2002). Although the influent $\mathrm{Ba}^{2+}$ concentration is more than 10 orders of magnitude higher than $\mathrm{Ra}^{2+}$, selectivity of the resin for $\mathrm{Ra}^{2+}$ still surpasses that for $\mathrm{Ba}^{2+}$. In comparison, the resin capacity for $\mathrm{Ba}^{2+}$ is estimated to be $0.033 \mathrm{meq} / \mathrm{g}$, which is $\sim 10^{6}$ times greater than for Ra (Table 3 ).

At influent concentrations of $98 \mathrm{mM}$ and $10.3 \mathrm{mM}$, respectively, $\mathrm{Ca}^{2+}$ and $\mathrm{Sr}^{2+}$ followed close trends in the breakthrough curves and required much shorter time to reach their influent levels (Fig. 2). The faster breakthrough is consistent with expected lower selectivity for these cations based on their smaller ionic radii (IR) compared with $\mathrm{Ba}^{2+}$ and $\mathrm{Ra}^{2+}$. With the smallest IR among the divalent cations, $\mathrm{Mg}^{2+}$ exhibited the weakest interaction with SAC resin and was detected in the effluent immediately after initiation of the experiment. Between 4.5 and 8.5 $\mathrm{BVs}, \mathrm{Mg}^{2+}$ concentration was observed to be greater than its influent level, suggesting a displacement of $\mathrm{Mg}^{2+}$ as a result of competition for exchange sites by other divalent cations. The three cations, that is, $\mathrm{Mg}^{2+}, \mathrm{Ca}^{2+}$, and $\mathrm{Sr}^{2+}$, consumed a combined capacity of $\sim 1.43 \mathrm{meq} / \mathrm{g}$, which accounted for $>90 \%$ of total capacity of the resin (Table 3). Clearly, Purolite C100E is not an $\mathrm{Ra}^{2+}$ selective resin, although it showed preferential removal of this radionuclide. With a sharp breakthrough curve, $\mathrm{Na}^{+}$was detected in the effluent almost immediately without any significant breakthrough. The high effluent concentration of $\mathrm{Na}^{+}$between one and nine BVs exceeds its influent level caused by release of $\mathrm{Na}^{+}$from initial $\mathrm{Na}$-saturated exchange sites after being replaced by divalent cations. It should be noted that while the influent $\mathrm{Na}^{+}$concentration $(0.65 \mathrm{M}$ or $15,000 \mathrm{mg} / \mathrm{L}$ ) is common for shale gas wastewater, it is substantially higher than $\left[\mathrm{Na}^{+}\right]$normally encountered in natural waters. Such high $\mathrm{Na}^{+}$concentration may negatively affect resin capacity for other cations by saturating resin sites, and in fact, concentrated $\mathrm{NaCl}$ solution (up to $2 \mathrm{M}$ ) flushes are often used to regenerate SAC resin by replacing previously sorbed cations after repeated flushing. At this high $\mathrm{Na}^{+}$concentration, the total divalent cation exchange capacity of the resin is $34 \%$ lower than the theoretical value ( $2.2 \mathrm{meq} / \mathrm{g}$ ) provided by the manufacturer, likely a result of substantial $\mathrm{Na}^{+}$competition.

\section{Impact of sodium and competing divalent cation concentrations on Ra removal}

Sodium ion is typically the most concentrated cation found in flowback wastewater, with the median $\mathrm{Na}^{+}$concentration in Marcellus Shale wastewater of $\sim 25,000 \mathrm{mg} / \mathrm{L}$ (Abualfaraj et al., 2014). To assess the impact of high $\mathrm{Na}^{+}$concentration on resin performance, experiments were performed in the absence of $\mathrm{Na}^{+}$(Experiment No. 2, Table 1). By removing $\mathrm{Na}^{+}$from the synthetic high-TDS water, the breakthrough of $\mathrm{Ra}^{2+}$ was delayed compared with the previous experiment using $0.65 \mathrm{M} \mathrm{Na}^{+}$. The removal capacity of the resin for $\mathrm{Ra}^{2+}$ increased by $\sim 50 \%$ to $0.36 \mathrm{nCi} / \mathrm{g}$ (Fig. 3 and Table 1 ). Clearly, a high concentration of $\mathrm{Na}^{+}$can significantly reduce $\mathrm{Ra}$ removal by the SAC resin. This reduction essentially results from $\mathrm{Na}^{+}$ions replacing or blocking trace quantities of $\mathrm{Ra}^{2+}$ from the exchange sites, causing an earlier $\mathrm{Ra}^{2+}$ breakthrough in effluent. Thus, the effective capacity of Purolite $\mathrm{C} 100 \mathrm{E}$ for $\mathrm{Ra}^{2+}$ would be limited unless the concentration of $\mathrm{Na}^{+}$is reduced before ion exchange.

To examine the influence of competing divalent cation concentration, that is, $\mathrm{Mg}^{2+}, \mathrm{Ca}^{2+}, \mathrm{Sr}^{2+}$, and $\mathrm{Ba}^{2+}$, on resin performance, an experiment was conducted using a synthetic

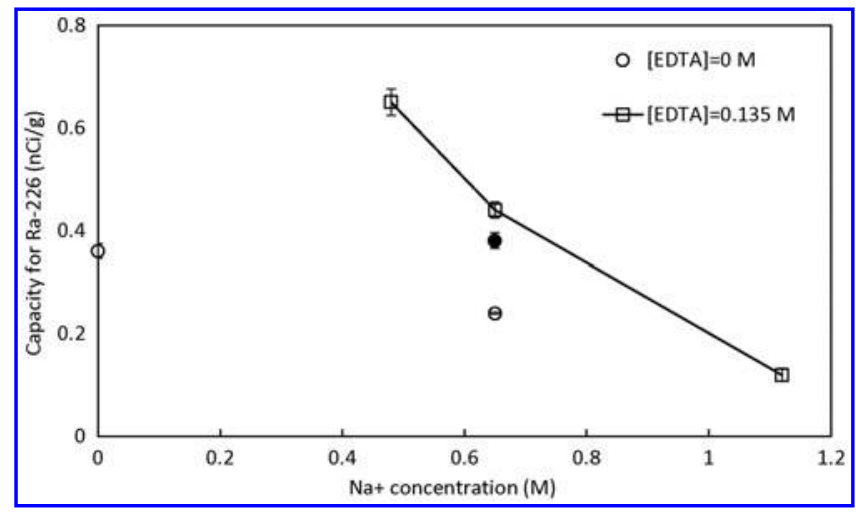

FIG. 3. Impact of $\mathrm{Na}^{+}$concentration (M) on resin capacity for $\mathrm{Ra}^{2+}$ removal $(\mathrm{nCi} / \mathrm{g}$ ) in the absence (circles) and presence (squares) of $0.135 \mathrm{M}$ EDTA. The filled circle represents the experiment with $0.65 \mathrm{M} \mathrm{Na}^{+}$and half the concentrations of divalent salts compared with the empty circle. 
brine with a $50 \%$ reduction in the original concentrations of divalent cations while keeping influent $\mathrm{Ra}$ at $10.6 \mathrm{nCi} / \mathrm{L}$ and $\mathrm{Na}^{+}$at $0.65 \mathrm{M}$ (Experiment No. 3, Table 1). The result (Fig. 3) shows that the capacity for $\mathrm{Ra}^{2+}$ increased from $0.24 \mathrm{nCi} / \mathrm{g}$ in Experiment No. 1 to $0.38 \mathrm{nCi} / \mathrm{g}$, responding to the lowered divalent ion concentrations. Compared with monovalent $\mathrm{Na}^{+}$, divalent cations have a greater impact on $\mathrm{Ra}^{2+}$ removal given that the sulfonated resin exchange sites generally have a greater affinity for higher charge cations. As noted previously, it is expected that divalent ions with larger IR, such as hydrated $\mathrm{Ba}^{2+}$, will be stronger competitors with $\mathrm{Ra}^{2+}$ for cation exchange sites than smaller ions, such as $\mathrm{Ca}^{2+}$ or $\mathrm{Mg}^{2+}$. By lowering the concentration of divalent cations in the brine solution, the efficiency of resin for $\mathrm{Ra}^{2+}$ removal would be expected to improve significantly.

$\mathrm{Ra}^{2+}$ removal efficiency significantly increased in an experiment with a lower total ion concentration (i.e., lower TDS, Experiment No. 4, Table 1). When both the monovalent and divalent cations were reduced to $1 / 10$ of the initial concentration in Experiment No. 1, the effluent concentration of $\mathrm{Ra}^{2+}$ remained negligible $(<0.1 \mathrm{nCi} / \mathrm{L})$ throughout the entire period of the experiment (up to $50 \mathrm{BVs}$ ). Along with the greater uptake on the resin and lower $\mathrm{Ra}^{2+}$ effluent concentration, the breakthrough of every other divalent cation was also significantly delayed. The more effective removal of $\mathrm{Ra}^{2+}$ translates to a resin capacity of $>0.46 \mathrm{nCi} / \mathrm{g}$, which is almost double the value in Experiment No. 1. Consistent with previous interpretation, the improved capacity for $\mathrm{Ra}^{2+}$ is primarily attributed to the low divalent salt concentration in synthetic wastewater. In most shale gas wastewaters, $\mathrm{Ra}^{2+}$ concentration is found to be positively correlated with the TDS concentration (Rowan, 2011). Given the large variation of TDS concentration in shale gas wastewater (Chapman et al., 2012), the effectiveness of ion exchange for $\mathrm{Ra}^{2+}$ removal is likely strongly dependent on both TDS concentration and composition of the water. For example, the highest $\mathrm{Ba}^{2+}$ concentration surveyed in Marcellus flowback water is two orders of magnitude greater than those used in the present study (Abualfaraj et al., 2014). When treating such brines, the ion exchange service time and resin capacity for $\mathrm{Ra}^{2+}$ removal are expected to be negatively impacted.

\section{Impact of EDTA on Ra removal}

EDTA is a strong hexadentate chelating agent and is widely used to dissolve limescale and sequester metal ions, such as $\mathrm{Ca}^{2+}$ and $\mathrm{Fe}^{3+}$. EDTA can be used in the treatment of high-TDS water to convert positively charged cations to negatively charged anions because of the negative charge of EDTA-metal complexes and the high equilibrium stability of metal-EDTA complexes (Supplementary Table S3). The capacity of resin for competitive divalent cations may hence be reduced, enhancing the capacity of resin for uncomplexed $\mathrm{Ra}^{2+}$. According to thermodynamic modeling results (Supplementary Fig. S1), EDTA preferentially forms complexes with cations following an order of $\mathrm{Ca}^{2+}>\mathrm{Mg}^{2+}>\mathrm{Sr}^{2+}>\mathrm{Ba}^{2+}$ $>\mathrm{Ra}^{2+}$ in a typical TDS composition for flowback wastewaters. To test its effect on $\mathrm{Ra}^{2+}$ removal, synthetic high-TDS water was amended with 0.135 M EDTA (Experiment No. 5, Table 1) based on equilibrium calculations so that $>99 \%$ of $\mathrm{Ca}^{2+}, \mathrm{Mg}^{2+}$, and $\mathrm{Sr}^{2+} ;>80 \%$ of $\mathrm{Ba}^{2+}$; and $<3 \%$ of $\mathrm{Ra}^{2+}$ became complexed by EDTA. The total metal concentrations in

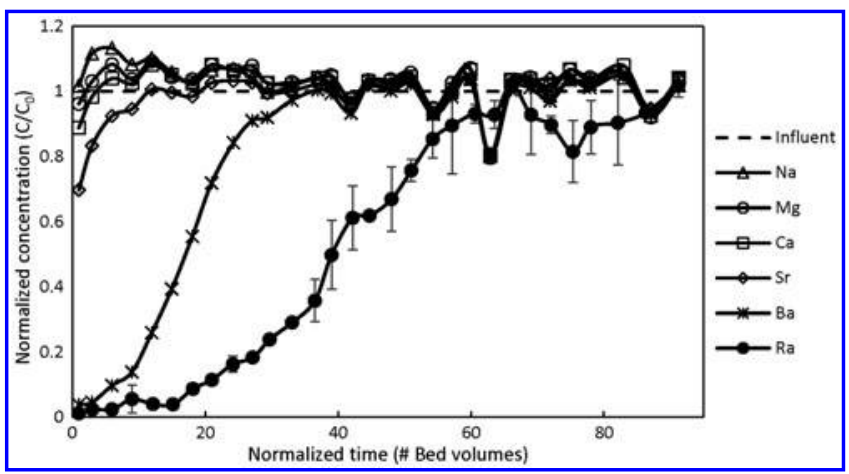

FIG. 4. Breakthrough curves of $\mathrm{Na}^{+}, \mathrm{Mg}^{2+}, \mathrm{Ca}^{2+}, \mathrm{Sr}^{2+}$, $\mathrm{Ba}^{2+}$, and $\mathrm{Ra}^{2+}$ in the presence of $0.135 \mathrm{M}$ EDTA. Data points of $\mathrm{Ra}^{2+}$ in the figure are the average of duplicate experiments; error bars represent the range of concentration determined in duplicate experiments.

the amended synthetic brine remained the same as in Experiment No. 1. The negatively charged metal-EDTA, such as Ba-EDTA ${ }^{2-}$, would pose less competition with Ra for sulfonate groups, and subsequently the capacity for removal of $\mathrm{Ra}$ would be enhanced.

The breakthrough of $\mathrm{Na}^{+}, \mathrm{Mg}^{2+}, \mathrm{Ca}^{2+}$, and $\mathrm{Sr}^{2+}$ in the resin column occurred almost immediately for the EDTA-amended brine (Fig. 4) as expected from speciation modeling. The breakthrough of $\mathrm{Ba}^{2+}$ also shifted to an earlier time compared with Fig. 2, while the exit of $\mathrm{Ra}^{2+}$ was delayed. The results demonstrated that EDTA improved separation of $\mathrm{Ra}^{2+}$ from other divalent mineral ions. The capacity of resin for $\mathrm{Ra}^{2+}$ increased to $0.42 \mathrm{nCi} / \mathrm{g}$, which was about 1.8 times the value without treatment by EDTA. It should be noted, however, that the effectiveness of EDTA treatment depends on its quantity relative to original salt concentrations in the brine. If the EDTA dose is excessively high, $\mathrm{Ra}^{2+}$ could also become complexed and negatively charged. In a subsequent experiment, $0.17 \mathrm{M}$ EDTA was added and more than $90 \%$ of $\mathrm{Ra}^{2+}$ was calculated to be transformed to Ra-EDTA ${ }^{2-}$. The breakthrough of $\mathrm{Ra}^{2+}$ thus occurred shortly after the start of experiment, causing significantly reduced $\mathrm{Ra}^{2+}$ removal of $0.04 \mathrm{nCi} / \mathrm{g}$. Therefore, when selecting an EDTA dose to complex competing divalent cations to enhance $\mathrm{Ra}^{2+}$ removal through ion exchange resins, the chemical composition of TDS in the wastewater would need to be relatively well characterized. Knowing the total concentrations of the competitive ions that may otherwise out-compete $\mathrm{Ra}^{2+}$ for exchange sites on the resin would be needed to optimize the treatment process for maximum $\mathrm{Ra}^{2+}$ removal efficiency. For wastewater accumulating in waste ponds, and waiting for treatment, this would likely be a relatively easily obtainable quantity.

\section{Impact of $\mathrm{Na}^{+}$on $\mathrm{Ra}^{2+}$ removal in the presence of EDTA}

Because $\mathrm{Na}^{+}$does not form strong complexes with EDTA, the presence of $\mathrm{Na}^{+}$ions in solution may have a negative impact on $\mathrm{Ra}^{2+}$ exchange on the resin, as noted previously, even when EDTA has been added. An experiment was performed to assess this possibility at the same $0.135 \mathrm{M}$ EDTA, but a higher $\mathrm{Na}^{+}$concentration of $1.12 \mathrm{M}$ (Experiment 
No. 8, Table 1). In this case, $\mathrm{Ra}^{2+}$ removal capacity of resin decreased to $0.12 \mathrm{nCi} / \mathrm{g}$ (Fig. 3 and Table 1). Conversely, by reducing the $\mathrm{Na}^{+}$concentration to $0.48 \mathrm{M}$ (Experiment No. 7, Table 1), the removal capacity for $\mathrm{Ra}^{2+}$ increased to $0.65 \mathrm{nCi} / \mathrm{g}$. Noticeably, however, even this high value of $\mathrm{Ra}^{2+}$ capacity of the resin was still significantly lower than the theoretical maximum value $(2.2 \mathrm{meq} / \mathrm{g})$ reported for the resin cation exchange capacity (Table 2). While the complexed divalent cations no longer exhibited strong competition with $\mathrm{Ra}^{2+}$ for exchange sites, the preponderance of $\mathrm{Na}^{+}$-bound sites still substantially diminished $\mathrm{Ra}^{2+}$ ion uptake by the resin. $\mathrm{Be}-$ cause EDTA was added to the solution in the form of disodium-EDTA, $\mathrm{Na}^{+}$was inherently present in the amended wastewater for the experiments in this study. In addition, to dissolve EDTA and facilitate metal complexation, the solution $\mathrm{pH}$ solution was adjusted to 6.0 by adding $\mathrm{NaOH}$ solution, which also increased the total $\mathrm{Na}^{+}$concentration. Since more $\mathrm{Na}^{+}$was introduced by adding EDTA, the present study was not optimal for enhancing $\mathrm{Ra}^{2+}$ removal. For instance, after adding $0.11 \mathrm{M}$ EDTA to a wastewater with the same composition as Experiment No. $1\left(0.65 \mathrm{M} \mathrm{Na}^{+}\right)$, the $\mathrm{Ra}^{2+}$ removal capacity of the resin $(0.23 \mathrm{nCi} / \mathrm{g})$ stayed relatively unchanged (Table 1). The resulting higher concentration of $\mathrm{Na}^{+}(0.93 \mathrm{M})$ essentially neutralized the potential effectiveness of EDTA amendment for $\mathrm{Ra}^{2+}$ removal. Thus, EDTA should be added at a concentration or chemical form that minimizes $\mathrm{Na}^{+}$addition to the extent possible to improve this process.

This work shows that the inclusion of a pretreatment step of adding EDTA can help improve $\mathrm{Ra}^{2+}$ removal through cation exchange by sequestering competing major divalent cations in high-TDS wastewater. However, implementation of the process relies on knowing the amount of EDTA that would need to be added (e.g., such as could be estimated based on TDS). In addition, the coincident introduction of $\mathrm{Na}^{+}$by a sodium EDTA salt form would need to be avoided to the extent possible to take full advantage of the beneficial effect of complexing the competing major divalent cations, that is, $\mathrm{Mg}^{2+}, \mathrm{Ca}^{2+}, \mathrm{Sr}^{2+}$, and $\mathrm{Ba}^{2+}$, in high-TDS brines. An initial treatment step for lowering the $\mathrm{Na}^{+}$concentration after EDTA addition may be necessary for getting the full benefit of adding EDTA. Alternatively, $\mathrm{Ra}^{2+}$ chelating ligands with greater selectivity over other divalent cations may be needed for optimizing ion exchange resins for effective $\mathrm{Ra}^{2+}$ removal from high-TDS wastewater (Chiarizia et al., 1998). The recent development of chelating agents, such as crown ethers, has shown promise for extracting $\mathrm{Ra}^{2+}$ from gas fieldproduced water (van Leeuwen et al., 2005). It is likely that generic cation exchange resins with sulfonate or diphosphonate groups can be functionalized with such compounds for improved selectivity and separation of $\mathrm{Ra}^{2+}$ from other constituents (Dietz et al., 1997), but the feasibility and effectiveness of more highly selective chelating agents will require further investigation.

\section{Conclusions}

Presence of radioactive Ra isotopes in shale gas wastewater poses a unique challenge to common pretreatment strategies because of its propensity to coprecipitate with scaling minerals (e.g., $\mathrm{BaSO}_{4(\mathrm{~s})}$ ). This study has demonstrated that a commercially available cation exchange resin
(Purolite C100E) can be utilized to separate radioactive $\mathrm{Ra}^{2+}$ from other salt constituents and remove $\mathrm{Ra}^{2+}$ from highsalinity brines commonly encountered during shale gas extraction. The removal efficiency by the resin strongly depended on TDS composition and concentration in the wastewater. Both monovalent and divalent ions can negatively affect $\mathrm{Ra}^{2+}$ removal by acting as competitors for resin exchange sites. Based on cationic charge, divalent cations (i.e., $\mathrm{Mg}^{2+}, \mathrm{Ca}^{2+}, \mathrm{Sr}^{2+}$, and $\mathrm{Ba}^{2+}$ ) exhibited a greater influence on $\mathrm{Ra}^{2+}$ removal by ion exchange resin than $\mathrm{Na}^{+}$. A pretreatment step of adding chelating agents could be used before $\mathrm{Ra}^{2+}$ removal through ion exchange to minimize the competition from divalent cations. The amendment of wastewater with EDTA was shown to improve $\mathrm{Ra}^{2+}$ removal by the same resin. However, the dose of EDTA needs to be carefully selected to prevent overdosing and formation of Ra-EDTA ${ }^{2-}$ complexes. High $\mathrm{Na}^{+}$concentration was shown to be an important factor in limiting $\mathrm{Ra}^{2+}$ removal efficiency. When using chelating agents such as EDTA, steps would need to be taken to keep Na salt addition as low as possible or to lower $\mathrm{Na}$ ion concentration following chelate addition for improving the resin capacity for $\mathrm{Ra}^{2+}$.

Among the current treatment technologies for shale gas wastewater, including osmosis, distillation, and electrodialysis, ion exchange has the highest selectivity for Ra removal and requires the least energy input (International Atomic Energy Agency, 2002; Crittenden and Montgomery Watson, 2012; Hickenbottom et al., 2013). This unconventional treatment strategy of metal chelation coupled with ion exchange resins may be effective in reducing the generation and disposal cost of low-level radioactive solid waste. It should be noted that inorganic components in the real flowback water are not limited to $\mathrm{Na}^{+}, \mathrm{Mg}^{2+}, \mathrm{Ca}^{2+}, \mathrm{Sr}^{2+}$, and $\mathrm{Ba}^{2+}$. The wastewater may also contain a range of organic contaminants, such as oil and grease, biocides, and other organic chemical additives used in the drilling process. To use ion exchange for $\mathrm{Ra}^{2+}$ removal, pretreatment to remove these impurities may also be necessary; however, the influence of these components on the effectiveness of this removal strategy (or other $\mathrm{Ra}^{2+}$ removal approaches) has yet to be investigated.

\section{Acknowledgment}

The authors would like to thank Tom Yavaraski for his technical assistance in ${ }^{226} \mathrm{Ra}$ analysis by ICP-MS. This research was supported by NSF CBET Grant No. 1336719 and a discretionary research account of the corresponding author (K.F.H).

\section{Author Disclosure Statement}

No competing financial interests exist.

\section{References}

Abo-Farha, S.A., Abdel-Aal, A.Y., Ashour, I.A., and Garamon, S.E. (2009). Removal of some heavy metal cations by synthetic resin purolite C100. J. Hazard. Mater. 169, 190.

Abualfaraj, N., Gurian, P.L., and Olson, M.S. (2014). Characterization of marcellus shale flowback water. Environ. Eng. Sci. 31, 514.

Boice, J., Jr., and Lubin, J. (1997). Occupational and environmental radiation and cancer. Cancer Causes Control. 8, 309. 
Chalupnik, S., Franus, W., Wysocka, M., and Gzyl, G. (2013). Application of zeolites for radium removal from mine water. Environ. Sci. Pollut. Res. 20, 7900.

Chapman, E.C., Capo, R.C., Stewart, B.W., Kirby, C.S., Hammack, R.W., Schroeder, K.T., and Edenborn, H.M. (2012). Geochemical and strontium isotope characterization of produced waters from Marcellus Shale natural gas extraction. Environ. Sci. Technol. 46, 3545.

Chiarizia, R., Horwitz, E.P., Dietz, M.L., and Cheng, Y.D. (1998). Radium separation through complexation by aqueous crown ethers and extraction by dinonylnaphthalenesulfonic acid. React. Funct. Polym. 38, 249.

Crittenden, J.C., and Montgomery Watson, H. (2012). MWH's Water Treatment: Principles and Design. Hoboken, NJ: John Wiley \& Sons.

Deng, S.G. (2005). Polymeric adsorbent for radium removal from groundwater. Adsorption. 11, 805.

Dietz, M.L., Chiarizia, R., Horwitz, E.P., Bartsch, R.A., and Talanov, V. (1997). Effect of crown ethers on the ion-exchange behavior of alkaline earth metals. Toward improved lon exchange methods for the separation and preconcentration of radium. Anal. Chem. 69, 3028.

El-Shrakawy, A., Ebaid, Y.Y., Burnett, W.C., and Aldaihan, S.K. (2013). A rapid and inexpensive method for Ra-226 and Ra-228 measurements of high TDS groundwaters. Appl. Radiat. Isot. 77, 89.

Fakhru'l-Razi, A., Pendashteh, A., Abdullah, L.C., Biak, D.R.A., Madaeni, S.S., and Abidin, Z.Z. (2009). Review of technologies for oil and gas produced water treatment. J. Hazard. Mater. 170, 530.

Fisher, R.S., (1995). Geologic, geochemical and geographic controls on NORM in Produced water from Texas Oil, Gas, and Geothermal Reservoirs. In SPE Paper 29709, presented at the SPE/EPA Exploration and Production Environmental Conference 95, sponsored by the Society of Petroleum Engineers and the U.S. Environmental Protection Agency. Houston, TX, pp. 195-205.

Fisher, R.S. (1998). Geologic and geochemical controls on naturally occurring radioactive materials (NORM) in produced water from oil, gas, and geothermal operations. Environ. Geosci. 139-150.

Grandia, F., Merino, J., and Bruno, J. (2008). Assessment of the radium-barium co-precipitation and its potential influence on the solubility of Ra in the near-field. In SKB Technical Report TR-08-07, Swedish Nuclear Fuel and Waste Management Co. Stockholm.

Gregory, K.B., Vidic, R.D., and Dzombak, D.A. (2011). Water management challenges associated with the production of Shale gas by hydraulic fracturing. Elements. 7, 181.

Hickenbottom, K.L., Hancock, N.T., Hutchings, N.R., Appleton, E.W., Beaudry, E.G., Xu, P., and Cath, T.Y. (2013). Forward osmosis treatment of drilling mud and fracturing wastewater from oil and gas operations. Desalination. 312, 60.
International Atomic Energy Agency. (2002). Application of ion exchange processes for treatment of radioactive waste and management of spent ion exchangers. In Technical Reports Series No. 408. IAEA, Vienna.

Kerr, R.A. (2010). Natural gas from Shale bursts onto the scene. Science. 328, 1624.

Moniz, E.J., Jacoby, H.D., Meggs, A.J.M., Armtrong, R.C., Cohn, D.R., Connors, S.R., Deutch, J.M., Ejaz, Q.J., Hezir, J.S., and Kaufman, G.M. (2011). The Future of Natural Gas. Cambridge, MA: MIT Press.

Radosavlevici, I.R., and Robescu, D.N. (2013). Demineralization of water with mixed-layer ion-exchangers. Environ. Eng. Manag. J. 12, 137.

Rahm, B.G., Bates, J.T., Bertoia, L.R., Galford, A.E., Yoxtheimer, D.A., and Riha, S.J. (2013). Wastewater management and Marcellus Shale gas development: Trends, drivers, and planning implications. J. Environ. Manag. 120, 105.

Rich, A.L. (2013). Analysis of reserve pit sludge from unconventional natural gas hydraulic fracturing and drilling operations for the presence of Technologically Enhanced Naturally Occurring Radioactive Material (TENORM). New Solut. 23, 117.

Rowan, E.L. (2011). Radium Content of Oil- And Gas-Field Produced Waters in the Northern Appalachian Basin (USA) Summary and Discussion of Data: U.S. Geological Survey Scientific Investigations Report, pp. 2011-5135.

Snoeyink, V.L., Pfeffer, J.L., Snyder, D.W., and Chambers, C.C. (1987). Removal of Barium and Radium From Groundwater, EPA/600/M-86/021, pp. 1-8.

U.S. Energy Information Administration. (2015). Annual Energy Outlook 2015. Washington, DC, DOE/EIA-0383.

U.S. Nuclear Regulatory Commission. (2013). Standards for protection against radiation - Appendix B- Radionuclide Table Radium-226. Rockville, MD: U.S. Nuclear Regulatory Commission. 10 CFR, 20.

van Leeuwen, F.W.B., Miermans, C.J.H., Beijleveld, H., Tomasberger, T., Davis, J.T., Verboom, W., and Reinhoudt, D.N. (2005). Selective removal of $226 \mathrm{Ra} 2+$ from gas-fieldproduced waters. Environ. Sci. Technol. 39, 5455.

Warner, N.R., Christie, C.A., Jackson, R.B., and Vengosh, A. (2013). Impacts of Shale gas wastewater disposal on water quality in Western Pennsylvania. Environ. Sci. Technol. 47, 11849.

Zhang, T., Gregory, K., Hammack, R.W., and Vidic, R.D. (2014). Co-precipitation of radium with barium and strontium sulfate and its impact on the fate of radium during treatment of produced water from unconventional gas extraction. Environ. Sci. Technol. 48, 4596.

Zhang, T., Hammack, R.W., and Vidic, R.D. (2015). Fate of radium in Marcellus Shale flowback water impoundments and assessment of associated health risks. Environ. Sci. Technol. 49, 9347. 
This article has been cited by:

1. Grasso Domenico, EES Editor-in-Chief, Peters Catherine A., EES Deputy Editor, Masten Susan J., Chair of the AEESP Publications Committee. 2017. AEESP Journal Spotlight: Early 2017. Environmental Engineering Science 34:2, 138-138. [Citation] [Full Text HTML] [Full Text PDF] [Full Text PDF with Links]

2. Clarens Andres F., Peters Catherine A.. 2016. Mitigating Climate Change at the Carbon Water Nexus: A Call to Action for the Environmental Engineering Community. Environmental Engineering Science 33:10, 719-724. [Abstract] [Full Text HTML] [Full Text PDF] [Full Text PDF with Links] 